\title{
PENGARUH BUSINESS INTELLIGENCE TERHADAP DUNIA BISNIS
}

\author{
Citra Berliani Utami ${ }^{1}$ \\ Lukman Faruk ${ }^{2}$ \\ Ofah Musyarrofah ${ }^{3}$
}

\author{
${ }^{1}$ STIE AL-Khairiyah, ${ }^{2}{ }^{3}$ Perguruan Tinggi Raharja \\ Email : citra.utami@gmail.com ${ }^{1}$, lukmanfaruk@raharja.info ${ }^{2}$, ofahmusyarrofah@raharj.info ${ }^{3}$
}

\begin{abstract}
Intense competition in the business world give effect to business people always renew the marketing and sales strategies. Especially at the present time, where business can be done by offline and online. And for online business, which are now all good business people who had long been involved or new must always have the latest sales and marketing strategies. Relating to the marketing and sales strategy, business intelligence can help online business which includes the companies. To obtain a clear knowledge of what are the factors that can affect the performance of the company. And after knowing the factors that affect to the performance then it can help the companies in making decisions and improve the strength to managed the business. Existing applications in business intelligence can be used to analyze consumer, product, and delivery channel is used. With business intelligence companies can manage and then processing the data into information that is not fixated on numbers only. Understand, improve performance, more cost efficient budgeting and identify new business oppurtunities and the benefits derived when companies implement business intelligence. The sale of product is not only determined by price and product itself because there are several other factors that influence and participating for buyer characteristic, geography, and still other factors too. Because of that's, the business intelligence needed. Where business and companies need tools, one of which is business intelligence to process data to be information of products sold so that the companies will be resulting decision taken by the business intelligence
\end{abstract}

Keyword : business, online, company, business intelligence

ABSTRAK

Ketatnya persaingan dalam dunia bisnis memberikan pengaruh terhadap para pelaku bisnis untuk selalu memperbaharui strategi pemasaran dan penjualannya. Khususnya pada saat sekarang, dimana bisnis dapat dilakukan secara offline dan online. Dan untuk bisnis online, yang sekarang semua pelaku bisnis baik yang sudah lama berkecimpung ataupun yang baru harus selalu memiliki strategi pemasaran dan penjualan terbaru. Berkaitan dengan strategi pemasaran dan penjualan, business intelligence dapat membantu pelaku bisnis online yang termasuk di dalamnya yaitu perusahaan, untuk memperoleh pengetahuan yang jelas tentang faktor - faktor apa sajakah yang dapat mempengaruhi kinerja perusahaan. Dan setelah mengetahui faktor - faktor apa saja yang berpengaruh terhadap kinerja, maka hal tersebut dapat membantu perusahaan dalam mengambil keputusan dan meningkatkan kekuatan dari usaha yang dikelola. Aplikasi yang ada pada business intelligence dapat dipakai untuk menganalisis konsumen, produk, dan delivery channel yang dipakai. Dengan adanya business intelligence, maka perusahaan dapat mengelola kemudian mengolah data menjadi informasi sehingga tidak terpaku pada angka - angka saja. Memahami,meningkatkan kinerja, penganggaran biaya yang lebih efisien, dan mengidentifikasi peluang bisnis baru merupakan manfaat yang diperoleh ketika perusahaan menerapkan business intelligence. Penjualan suatu produk tidak hanya ditentukan oleh harga dan kualitas produk saja, karena ada beberapa faktor lain yang ikut mempengaruhinya diantaranya adalah karakteristik pembeli, faktor geografi, dan masih ada faktor lainnya. Karena faktor-faktor tersebut peran dari business intelligence sangat diperlukan. Dimana pelaku bisnis ataupun perusahaan memerlukan alat bantu yang salah satunya adalah business intelligence untuk mengolah data untuk menjadi informasi dari produk yang dijual sehingga nantinya akan dihasilkan keputusan yang akan diambil oleh pelaku bisnis atau perusahaan tersebut.

Kata Kunci: bisnis, online, perusahaan, business intellige

Vol.1 No.1 - Agustus 2015 


\section{PENDAHULUAN}

Business Intelligence ( BI ) menurut DJ Power dalam bukunya yang berjudul $A$ Brief History of Decision Support Systems: 2002, mengatakan bahwa " Business Intelligence menjelaskan tentang suatu konsep dan metode bagaimana untuk meningkatkan kualitas pengambilan keputusan bisnis berdasarkan sistem yang berbasiskan data. Business Intelligence seringkali dipersamakan sebagaimana briefing books, report, and query tools, dan sistem informasi eksekutif. Business intelligence ( $\mathrm{BI}$ ) merupakan sistem pendukung pengambilan keputusan yang berbasiskan data - data". Business intelligence adalah rangkaian aplikasi dan teknologi untuk mengumpulkan, menyimpan, menganalisis, dan menyuguhkan akses data untuk membantu petinggi perusahaan dalam pengambilan keputusan ( Stevans, 2008 ). Sedangkan menurut Nadia Branon, business intelligence merupakan kategori yang umum digunakan untuk aplikasi dan teknologi untuk mengumpulkan, menyimpan, menganalisa, dan menyediakan akses pada data agar dapat membantu dari kalangan perusahaan agar dapat mengambil keputusan dengan lebih baik dan tepat (Rina Indriyani, 2013, )Secara umum BI merupakan sebuah proses untuk melakukan ekstraksi data - data operasional perusahaan dan mengumpulkannya dalam sebuah data warehouse yang selanjutnya diproses menggunakan berbagai analisis statistik dalam proses data mining sehingga didapat berbagai kecenderungan atau pattern dari data ( Choirul, 2006 ).

Pertama kalinya istilah business intelligence digunakan yaitu tahun 1958 oleh seorang peneliti dari IBM yaitu Hans Peter Luhn, dan kemudian beliau mendefinisikan business intelligence sebagai " kemampuan dalam mengerti dan memahami suatu hubungan timbal balik antara fakta - fakta yang disajikan sedemikian rupa menjadi suatu landasan dalam bertindak untuk mencapai suatu tujuan yang dikehendaki “. Dengan perkembangan decision support jika tidak didukung oleh data - data pendukung.

Karena itulah, teramat penting bagi pelaku bisnis untuk mulai membenahi data data yang ada secara terstruktur. Sebab, apabila dibutuhkan analisa profitabilitas system yang dimulai sejak tahun 1960an sampai dengan tahun 1980an maka business intelligence mulai mendapatkan perhatian dan kemudian akhirnya menjadi suatu kesatuan dari sistem. Dan pada tahun 1989, artikel terbitan Gartner, Howard Dresner memakai istilah business intelligence untuk mendeskripsikan seperangkat konsep dan metode yang berguna untuk meningkatkan kemampuan pembuatan keputusan dengan bantuan sistem yang berbasiskan fakta atau realita yang terjadi.

Osfir Corporation melalui postingan artikel Firdaus Aulia pada 1 Maret 2012 mendefinisikan Bisnis Online adalah segala kegiatan (bisnis/urusan/kepentingan) yang menggunakan fasilitas internet untuk mencapai tujuan (keuntungan/profit). Dengan ketatnya persaingan bisnis maka sangat diperlukan analisis data sebagai cara untuk tetap bertahan dalam dunia bisnis, analisis data yang cermat dibutuhkan dalam proses pengambilan keputusan. Analisis data telah menjadi kebutuhan vital untuk meningkatkan persaingan pada dunia bisnis. Menggunakan intuisi dalam pengambilan keputusan sudah tidak lagi relevan dalam persaingan bisnis yang semakin ketat. Jumlah penjualan yang terkadang naik dan turun tidak lagi dikarenakan oleh murah dan mahalnya harga penjualan dan juga tidak lagi dikarenakan oleh baik dan buruknya kualitas dari produk. Perusahaan memerlukan alat bantu yang mampu untuk mengolah data - data menjadi informasi bernilai lebih dan tidak terpaku pada angka - angka saja. Alat bantu tersebut harus mampu untuk menerjemahkan berbagai hal dan gejala - gejala penting dari sekumpulan data yang ada. Dan salah satu alat bantu tersebut adalah business intelligence ( BI ). Sebenarnya masih banyak hal lain yang bisa dilakukan oleh BI khususnya dalam menampilkan berbagai informasi yang berguna untuk perusahaan, dan yang tidak boleh dilupakan adalah bahwa BI adalah hanya sebuah alat analisis data. Yang artinya sistem ini tidak akan maksimal

konsumen, produk, saluran distribusi, ataupun program promosi, maka sudah tersedia data yang akurat, sehingga hasil dari analisis yang dilakukan dapat digunakan untuk pengambilan keputusan. Konsep dari business intelligence ( BI ) menekankan pada 
5 ( lima ) pendayagunaan informasi yang digunakan untuk keperluan bisnis ( Moss, L.T \& Shaku, A. ( 2003 ). Business Intelligence Roadmap : The Complete Project Lifecyle for Decision-Support Application. Boston: Addison Wesley. Kelima ( 5 ) pendayagunaan yang dimaksud adalah sebagai berikut :

\section{Data Sourcing}

Dalam hal ini business intelligence memiliki kemampuan untuk dapat mengakses berbagai sumber data dan informasi yang berada pada sejumlah sumber yang berbeda dimana pada setiap sumber memiliki format penyimpanan data yang berbeda pula.

\section{Data Analysis}

Dalam hal ini BI memiliki kemampuan untuk dapat menganalisis data yang didapatkan dari aktifitas perusahaan dan informasi dari perusahaan sehingga dapat dijadikan sebuah pengetahuan yang kelak dapat digunakan perusahaan untuk meningkatkan kinerja perusahaan.

3. Situation Awareness

Dalam hal ini BI memiliki kemampuan untuk dapat menyediakan sebuah sistem yang dapat digunakan untuk mencari dan memberikan data serta informasi yang dibutuhkan oleh perusahaan ketika perusahaan menghadapi kejadian darurat atau terdesak.

4. Risk Analysis

Dalam hal ini BI memiliki kemampuan untuk dapat memberikan

\section{PERMASALAHAN}

Bisnis online memang memiliki banyak keunggulan dibandingkan dengan bisnis yang offline. Perkembangan internet yang sangat pesat akan menimbulkan persaingan dunia bisnis yang cukup ketat, karena setiap harinya akan muncul pelaku bisnis yang mengenalkan produknya dengan kreatifitas dan inovasi baru sehingga persaingan bisnis tidak akan bisa dihindarkan lagi. Maka, apabila pelaku usaha online tidak berusaha menjadi diri yang kreatif dan perhitungan resiko yang akan dihadapi perusahaan terhadap berbagai kemungkinan yang terjadi akibat dari pilihan - pilihan tertentu yang diambil oleh perusahaan.

5. Decision Support

Dalam hal ini BI memiliki kemampuan untuk dapat memberikan pertimbangan - pertimbangan yang dapat digunakan untuk membantu perusahaan dalam pengambilan keputusan yang dapat digunakan untuk membantu perusahaan dalam pengambilan keputusan - keputusan yang berkualitas yang diambil berdasarkan berbagai perhitungan dan pengolahan terhadap data atau informasi baik internal maupun eksternal yang dimiliki oleh perusahaan.

Jika pada lembaga bisnis, business intelligence dimanfaatkan untuk meningkatkan kinerja melalui pemilihan strategi bisnis yang tepat, maka pada lembaga non - profit business intelligence dapat digunakan untuk meningkatkan kinerja perusahaan melalui peningkatan efisiensi pelaksanaan kerja sehingga pada akhirnya akan tercipta perbaikan layanan pada masyarakat serta pengelolaan anggaran yang tepat.

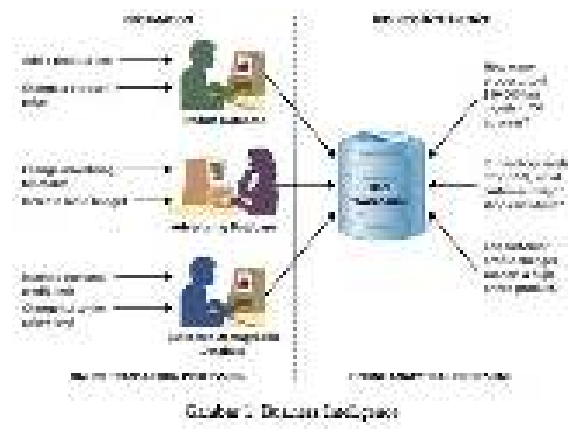

inovatif, maka usahanya akan jauh tertinggal dengan pelaku bisnis yang baru. Banyak sekali perangkat lunak yang tersedia untuk membuat sistem informasi, salah satunya yaitu dengan menggunakan perangkat lunak berbasis web. Kini proses tersebut sangat terbantu dengan adanya internet (Davis, 2005: 54). Business intelligence ( BI ) adalah aplikasi e-business yang berfungsi untuk mengubah data seperti data transaksi dan data - data pendukung lainnya untuk diubah ke 
dalam bentuk pengetahuan. Business intelligence dapat melakukan analisa data dengan lebih efektif, contoh dalam menganalisa loyalitas pembeli sehingga meningkatkan keuntungan perusahaan atau bisnis yang sedang dijalankan.

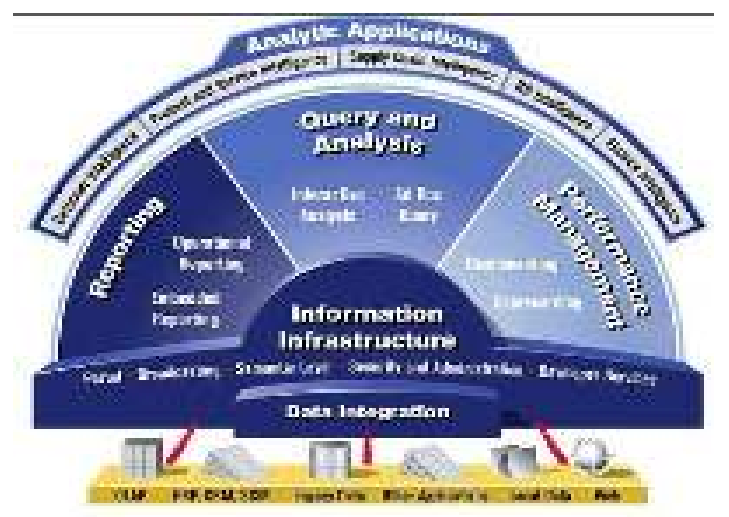

Gambar 2. Fungsi Business Intelligence

Dari penjelasan diatas, dapat dirumuskan beberapa permasalahan yaitu sebagai berikut :

1. Bagaimana menyediakan informasi yang berbeda - beda dan khusus untuk pelanggan?

2. Faktor apa sajakah yang harus dijadikan perhatian agar perusahaan dapat mengintegrasikan business intelligence ke dalam proses bisnis perusahaan?

3. Prosedur apa sajakah yang dilakukan untuk menghubungkan business intelligence ke dalam proses bisnis perusahaan?

4. Analisis data yang seperti apakah yang dapat dilakukan sehingga dapat dijadikan acuan dalam pengambilan keputusan?

5. Hal-hal apa saja yang bisa menghambat aplikasi business intelligence pada aktifitas bisnis online?

\section{LITERATURE REVIEW}

Banyak penelitian yang dilakukan mengenai e-Business, Business Intelligence, dan Bisnis Online beserta aplikasi pendukungnya. Untuk mengaplikasikan business intelligence pada bisnis online diperlukan adanya beberapa studi pustaka sebagai penerapan metode penelitian yang akan dilakukan. Hal ini dilakukan untuk mengetahui metode apa yang pernah dilakukan, supaya tidak terjadi perulangan, melanjutkan penelitian yang sudah pernah dilakukan, dan mengetahui spesialisasi orang lain yang penelitiannya sama di bisnis online juga. Beberapa literature review yang berkaitan adalah sebagai berikut :

1. Penelitian tentang Perkembangan $e$ Business Terhadap Perkembangan Praktik Bisnis yang dilakukan oleh Herman, Yakub Jurusan Tehnik Informatika STIMIK Dharma Putra Tangerang pada tahun 2010, mengatakan bahwa perkembangan teknologi informasi mengakibatkan perubahan dalam struktur serta praktik pengelolaan organisasi bisnis di dalam berkompetisi. Ruang lingkup e-Business lebih luas dimana cakupannya meliputi layanan pelanggan, kerjasama dengan mitra bisnis, dan juga adanya transaksi elektronik. Pada saat ini e-Business memberikan pengaruh yang sangat positif terhadap perdagangan terutama terhadap para pelakunya yaitu produsen/pemasok/supplier, konsumen/pembeli, dan perantara. Selain itu dengan adanya e-Business menuntu para pelaku bisnis untuk lebih meningkatkan kreatifitas, inovasi, kompetisi dan komitmen.

2. Penelitian tentang Analisis dan Perancangan Sistem Informasi Untuk Siklus Pembelian Dan Penjualan Dalam Pengembangan Bisnis Online Shop Pada “ Holly Shop" Di Surabaya oleh Mery Meliyanti Lasakar Jurnal Ilmiah Mahasiswa Universitas Surabaya Vol 2 No 2 ( 2013 ) ada 2 hambatan yang dihadapi oleh Holly Shop yang melakukan bisnis online yaitu 1. Hambatan yang berhubungan dengan sistem informasi yang diantaranya adalah stok barang terbatas, kapasitas menampung pelanggan yang terbatas, kekecewaan pelanggan akibat lamanya kedatangan barang pre order, kesulitan dan kegagalan dalam penagihan piutang kepada pelanggan, barang cacat, kurangnya sumber daya manusia, ketidakpuasan 
pelanggan sedangkan yang ke 2 . Hambatan non sistem diantaranya adalah konsumen yang tidak bertanggung jawab, keterlambatan pengiriman dari ekspedisi, dan gangguan sinyal. Sehingga dapat ditarik kesimpulan bahwa dengan semakin meningkatnya kemajuan teknologi informasi dan komunikasi apalagi internet maka akan semakin membuka peluang yang sangat besar untuk membuka penjualan secara online. Dalam bisnis online kepercayaan pelanggan sangat sulit untuk didapat dan begitu sudah didapat maka kita sebagai penjual harus memberikan pelayanan dan bonus yang maksimal, dan yang tidak kalah penting adalah tanpa adanya struktur organisasi maka pelaksanaan bisnis online tidak akan bertahan lama.

3. Penelitian tentang Peran Sosial Media Untuk Manajemen Hubungan Pelanggan Pada Layanan $e$ Commerce yang dilakukan oleh Bambang Supradono Fakultas Tehnik Universitas Muhammadiyah Semarang dan Ayu Noviani Hanum Fakultas Ekonomi Universitas Muhammadiyah Semarang pada tahun 2011, yang mengatakan bahwa penggunaan media sosial seperti facebook, twitter, google dan lainlain melalui media internet semakin tren di masyarakat sehingga mempengaruhi perubahan perilaku dimasyarakat dalam berkomunikasi dan berinteraksi. Keunggulan media sosial inilah yang memberikan komunikasi dua arah antara konsumen dengan perusahaan dan konsumen dengan konsumen. Komunikasi dua arah ini memacu konsumen untuk berpartisipasi, berkolaborasi dan berinteraksi dimana pada intinya konsumen tidak lagi menjadi obyek pemasaran melainkan menjadi subyek pemasaran

4. Penelitian tentang Analisis FaktorFaktor Yang Mempengaruhi

6. Informatika Politeknik Negeri Sriwijaya tahun 2011 yang mengatakan bahwa penggunaan
Keputusan Pembelian Melalui Social Networking Websites yang dilakukan oleh Abdurrahman Adi Sukma Fakultas Ekonomi Universitas Gunadarma pada tahun 2012 yang mengatakan bahwa di dalam dunia pemasaran internet seorang $e$ marketer tidak dapat mengabaikan peran Social Networking Websites sebagai media komunikasi pemasaran mereka. Dimana aktifitas pemasaran melalui Social Networking Websites memungkinkan e-marketer menerapkan strategi pemasaran yang interaktif sehingga konsumen dapat bersikap proaktif dan interaktif dalam kegiatan pemasaran. Hal - hal yang menentukan tingkat pembelian melalui social networking websites adalah trust, quality of service, dan perceived risk. Dimana ketiga hal tersebut harus dilakukan untuk meningkatkan peningkatan penjualan, mengembangkan usaha, dan mempertahankan kelangsungan hidup dari usaha mereka. Untuk mencapainya dapat dilakukan dengan cara-cara seperti meningkatkan profesionalitas, kredibilitas, kualitas produk, dan mempermudah proses transaksi pembayaran, selain itu juga memilih ekspedisi yang akan mempercepat proses pengiriman, memilih pemasok yang memberikan harga paling murah, menjaga komunikasi dengan pelanggan, serta memberikan kemudahan kepada konsumen untuk mencari barang dan jasa yang dibutuhkan oleh konsumen. Mengetahui apa yang konsumen harap dan inginkan, konsisten dalam memberikan pelayanan yang baik dari awal hingga akhir proses transaksi adalah beberapa cara untuk meningkatkan kualitas pelayanan terhadap pelanggan.

5. Penelitian tentang Pemanfaatan $e$ Commerce dalam dunia bisnis yang dilakukan oleh Dewi Irmawati Staf Pengajar Jurusan Manajemen

internet dalam dunia bisnis berubah dari fungsi sebagai alat untuk pertukaran informasi secara 
elektronik menjadi alat untuk aplikasi strategi bisnis seperti pemasaran, penjualan dan pelayanan pelanggan. Pemasaran di internet mampu menembus berbagai rintangan, batas antar bangsa, dan tanpa aturan - aturan yang baku. Dengan pemanfaatan dan penggunaan teknologi internet diharapkan dapat memberikan manfaat yang besar dalam dunia bisnis yang kompetitif. Salah satu jenis implementasi teknologi dalam hal meningkatkan persaingan bisnis dan penjualan produk - produk adalah dengan menggunakan ecommerce untuk memasarkan berbagai macam produk atau jasa, baik dalam bentuk fisik maupun digital. Dengan adanya pelayanan $e$ commerce maka pelanggan atau pembeli dapat melakukan proses pembelian atau pemesanan dari berbagai tempat.

7. Penelitian tentang Pengembangan Business Intelligence Bagi Perkembangan Bisnis Perusahaan oleh Eka Miranda Jurusan Sistem Informasi Fakultas Ilmu Komputer Universitas Bina Nusantara Volume 02 Nomor 02 Oktober 2008 yang mengatakan bahwa business intelligence memungkinkan pengambil keputusan berbuat berdasarkan intelligence yang berdasarkan BI. Jika pengetahuan atau informasi tidak digunakan dengan tepat pada arah yang tepat juga maka analisis pada business intelligence akan sangat sulit untuk dilakukan. BI berisikan tentang strategi untuk meningkatkan proses bisnis secara efisien tanpa mengurangi biaya operasional pada proses bisnis yang sedang berjalan atau yang sedang dilakukan oleh perusahaan tersebut.

8. Penelitian tentang Business Intelligent Systems : Bentuk Optimalisasi Pengambilan Keputusan Pada Level Manajemen oleh Dwi Iswanto Tehnik Informatika STIMIK AMIKOM Yogyakarta 2011 yang yang tentunya tidak sedikit jumlahnya. Dalam proses bisnis, perusahaan mengatakan bahwa business intelligence adalah proses - proses, alat bantu dan teknologi untuk mengubah data menjadi informasi dan informasi menjadi pemahaman serta rencana untuk menggerakan aktifitas bisnis yang efektif. Dengan adanya BI, maka dapat meningkatkan kualitas dalam persaingan bisnis. Untuk membangun kemampuan agar tetap dapat bersaing dalam bisnis modern, maka pelaku bisnis harus selalu mencari cara terbaru dalam meningkatkan produktifitas dan keefisiensian dalam infrastruktur perusahaan yang dimulai dari kegiatan back office - front office sampai dengan tingkat manajemen baik itu manajemen pemasaran, produksi, dan manajemen keuangan.

\section{PEMECAHAN MASALAH}

Dari berbagai permasalahan yang ada dan yang dihadapi oleh penerapan aplikasi business intelligence pada akhirnya akan memberikan dampak terhadap dunia bisnis. Dari segi proses bisnis, pengelolaan informasi - informasi merupakan hal yang sangat penting karena kemampuan bisnis suatu perusahaan dalam memanfaatkan informasi dan menyampaikan strategi berdasarkan informasi yang telah tersedia menjadi suatu alat yang sangat ampuh dalam proses pengambilan keputusan dari aktifitas bisnis tersebut. Jelas business intelligence diperlukan di setiap proses bisnis suatu perusahaan untuk mencapai tujuan perusaahn yang lebih baik, lebih efisien, dan efektif yang nantinya akan menghasilkan tingkat keuntungan yang maksimal. Business intelligence merupakan suatu proses yang mengumpulkan kemudian mengubah sebagian besar data yang terdapat pada proses bisnis dalam perusahaan menjadi informasi yang berguna. Implementasi business intelligence dalam suatu bisnis perusahaan membutuhkan biaya yang tidak sedikit karena memerlukan proses yang panjang kemudian memerlukan analisa yang sangat teliti dan tentu saja investasi uang

menggunakan business intelligence untuk memperoleh lebih banyak informasi yang 
berhubungan dengan kinerja bisnis perusahaan. Selain itu, business intelligence akan dimanfaatkan untuk memahami, meningkatkan kinerja, menganggarkan biaya yang lebih efisien kemudian mengidentifikasikan jenis peluang bisnis apa saja yang terbaru.

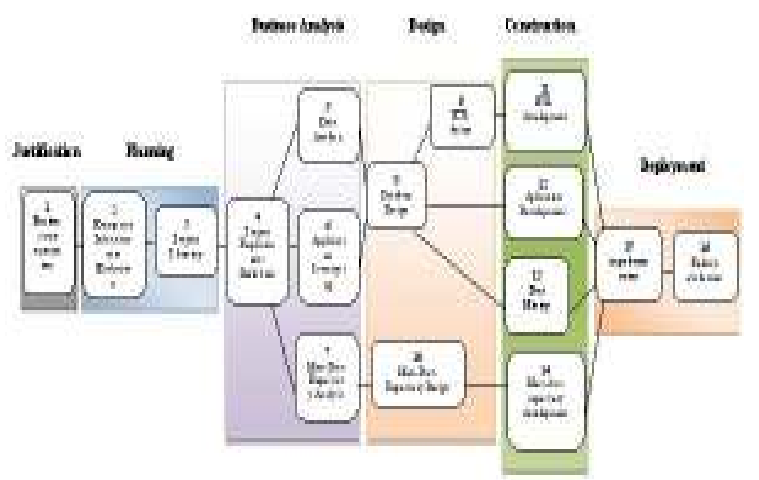

Gambar 3. Tahap Pengembangan Business Intelligence

Beberapa kegunaan business intelligence pada proses bisnis suatu perusahaan, diantaranya adalah sebagai berikut :

1. Menganalisa perilaku konsumen, pola pembelian, dan tren penjualan

2. Mengukur, melacak, dan memperkirakan penjualan dan kinerja keuangan

3. Menganggarkan, perencanaan keuangan dan peramalan

4. Mengetahui kinerja dari divisi pemasaran

5. Optimalisasi proses dan kinerja operasional

6. Meningkatkan efektifitas pengiriman dan pasokan

7. Analisa customer relationship management

8. Analisa resiko

9. Analisa nilai strategis

10. Dan analisa media sosial

Mengimplementasikaan business intelligence pada proses bisnis suatu perusahaan bukan hanya menanamkan investasi dan membiarkan BI berjalan dengan sendirinya. Melainkan perusahaan harus bergerak dengan cepat dalam menjalankan proses bisnisnya menyesuaikan dengan kemajuan teknologi dan informasi yang pelanggan adalah strategi bisnis baru yang dapat memenangkan pasar nantinya. Apalagi sangat berpengaruh terhadap strategi bisnis dan tujuan dari perusahaan. Menyamakan strategi business intelligence dengan strategi bisnis perusahaan akan memberikan banyak keuntungan. Ketika suatu perusahaan menentukan tujuan dari bisnisnya maka harus diperhatikan beberapa hal yang diantaranya adalah mengidentifikasikan kebutuhan pada setiap bagian/tahapan, menentukan kapan tahapan dimulai, dan kemudian mengukur sampai mana keberhasilan setiap tahapan dalam mencapai tujuan. Dan yang terakhir adalah mengukur tingkat loyalitas dari pembeli, sampai seberapa jauh mereka loyalitas terhadap perusahaan. Jika strategi bisnis sudah seimbang dengan strategi business intelligence dalam hal ini adalah loyalitas pelanggan, maka perusahaan akan dengan mudah untuk mengukur kemajuan untuk mencapai tujuan perusahaan. Kelebihan dari keseimbangan strategi business intelligence dengan strategi bisnis perusahaan adalah mengarahkan divisi teknologi informasi kearah mana investasi BI harus dilakukan dan jenis proses apa yang harus dijadikan prioritas utama.

\section{IMPLEMENTASI}

Pada umumnya business intelligence adalah proses melakukan ekstraksi data data operasional perusahaan dan mengumpulkannya dalam suatu data warehouse. Kemudian data yang ada pada data warehouse akan diproses menggunakan berbagai analisa statistik dalam proses data mining yang kemudian akan didapatkan berbagai kecenderungan atau pattern dari data. Hasil akhir dari proses ini akan diberikan ke end user sehingga manajemen dapat mengambil keputusan berdasarkan fakta - fakta aktual, tidak mengandalkan intuisi dan pengalaman semata. Setiap perusahaan pasti akan berusaha untuk melayani dan memenuhi kebutuhan pembelinya dengan sebaik mungkin. Hal ini dilakukan untuk mempertahankan bisnis yang sedang berjalan yang disebabkan oleh pengaruh persaingan yang sangat ketat sekarang ini. Bisnis perusahaan pada jaman sekarang tidak hanya berorientasi pada 4P yaitu Price, Product, Place, dan Promotion. Dr Philip Kotler mengatakan, fokus pada jika perusahaan tersebut sudah mengintegrasikan metode get, keep, and 
grow dengan menggunakan teknologi yang dapat membantu mengatur hubungan antara perusahaan dengan pelanggannya. Banyak aplikasi business intelligence yang menggunakan data yang diperoleh dari data warehouse atau data mart, padahal tidak semua data warehouse dapat dipakai untuk BI begitu juga sebaliknya. Penggunaan dashboard yang merupakan pendukung dari BI sebagai daasarnya, maka perusahaan dapat meningkatkan loyalitas pembeli dengan cara melakukan monitoring dan controlling indikator - indikator penting yang berpengaruh pada kesuksesan dalam mempertahankan pelanggan . Dan nantinya dashboard ini akan bermanfaat untuk membantu pengambilan keputusan bagi perusahaan untuk menentukan dan kemudian mengambil langkah selanjutnya untuk mempertahankan loyalitas pelanggannya. Dan kebutuhan ini akan selalu berubah setiap waktunya mengikuti perkembangan dari bisnis itu sendiri.

Agar efektif, aplikasi BI harus diintegrasikan dengan lancar ke pekerjaan end - user yang terlibat. Maksudnya adalah pada saat end - user sedang melakukan tugasnya seharusnya mereka tidak mengalami saat mengakses informasi yang dibutuhkan. Kemudian, end - user memanipulasi informasi agar sesuai dengan apa yang mereka butuhkan. Aplikasi aplikasi spreadsheet dan database yang digunakan oleh end - user dalam pekerjaan mereka, terkadang tidak sesuai dengan ruang lingkup dari business intelligence itu sendiri. Untuk mengurangi dampak hal ini, analisa yang berorientasi pada proses harus dijalankan. Tujuannya adalah untuk memahami proses tersebut dan selanjutnya mendefinisikan kebutuhan dari setiap proses bisnis, diantaranya adalah :

1. Informasi

Informasi apa yang dibutuhkan untuk mendukung personil yang terkait dengan aktifitasnya?

2. Format

Bagaimana informasi disampaikan ke personil terkait untuk dukungan lebih baik dalam aktifitasnya ? apakah dalam wujud kertas atau layar komputer ? Bagaimana format informasi apakah cukup list sederhana, laporan dengan banyak tab atau berbentuk diagram?
3. Fungsionalitas

Sebagai pelengkap dalam penyampaian informasi, apakah penerima informasi masih perlu untuk menelusuri informasi tersebut, seperti slice and dice ? Apakah mereka butuh perhitungan berdasarkan informasi yang diperoleh? Hal lain apa yang harus disediakan oleh business intelligence untuk mereka.

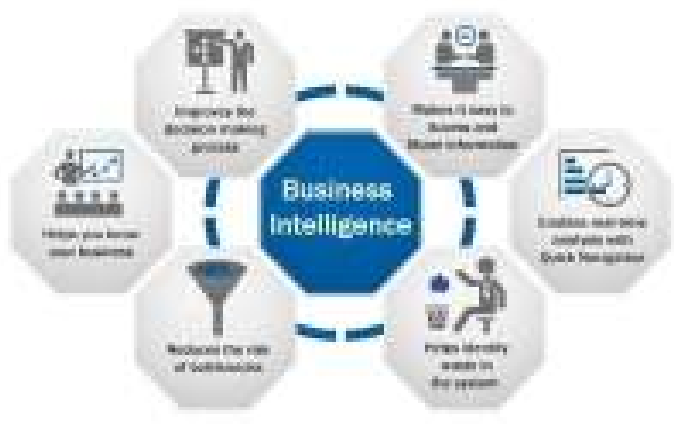

Gambar 4. Fungsi Business Intelligence

Dalam bidang pemasaran, aplikasi BI dapat digunakan untuk menganalisa konsumen, produk, dan juga delivery channel yang digunakan. Aplikasi nantinya akan digunakan untuk menganalisa tingkat keuntungan dan efektifitas masing - masing hal. Pertama, aplikasi BI dipakai untuk menghitung tingkat profitabilitas setiap konsumen atau setiap segmen. Pada proses ini, BI akan membantu menganalisis biaya yang dikeluarkan perusahaan untuk melayani setiap segmen konsumen dan dibandingkan dengan penerimaan perusahaan sehingga perusahaan bisa mengetahui segmen konsumen mana yang menguntungkan ataupun merugikan. Bagi manajemen, informasi ini sangat penting untuk mengambil keputusan segmen mana yang akan dilayani ataupun segmen mana yang harus diprioritaskan dalam pelayanannya. Sedangkan dari sisi konsumen, BI dipakai untuk menganalisa customer lifetime value ( CLV ). CLV inuntuk i digunakan menghitung berapa nilai konsumen bagi perusahaan di masa yang akan datang. Intinya adalah CLV digunakan untuk memprediksi berapa produk/jasa yang akan dibeli oleh konsumen di masa depan, berdasarkan data historis pembeliannya dan kemungkinan adanya cross selling dari 
produk lain. Kegunaan lain dari BI adalah untuk menilai tingkat efektifitas saluran distribusi. Seperti halnya saat menganalisa konsumen, setiap saluran distribusi dihitung berapa biaya yang dikeluarkan dibandingkan dengan penerimaan perusahaan melalui saluran tersebut. Dari hal ini, informasi tentang efektifitas dan profitabilitas suatu saluran distribusi dengan mudah diketahui ( SWA Online, 2004 ).

\section{KELEBIHAN}

Dengan business intelligence manajemen akan memperoleh informasi yang berkualitas dari kegiatan bisnisnya secara tepat waktu, akurat, dan reliable melalui saluran komunikasi data sehingga memudahkan pimpinan perusahaan dalam proses pengambilan keputusanyang penting dan bersifat strategis. Semakin tinggi tingkat kompetisi antar perusahaan, maka peranan business intelligence sangat penting, sehingga dapat disebutkan kelebihan dari BI adalah sebagai berikut :

1. Konsolidasi informasi

2. In-depth reporting

3. Customized graphic user interface

4. Sedikit masalah teknis

5. Biaya pengadaan rendah

6. Flexible databank

7. Responsiveness

\section{KEKURANGAN}

\section{Meskipun ada kelebihan dari business intelligence tetapi tetap saja business intelligence memiliki kekurangan. Kesulitan utama dari pengimplementasi BI adalah pengintegrasiannya terhadap perusahaan terutama pada proses bisnisnya. Dan beberapa kekurangan dari business intelligence adalah sebagai berikut : \\ 1. Kebingungan terhadapa arti data, hal ini dikarenakan tidak adanya pemahaman yang sama mengenai definisi data}

2. Aplikasi BI tidak mampu mengikuti perubahan yang tidak teratur, maksudnya adalah setiap perusahaan akan merubah tujuan dari bisnis setiap tahunnya, dan perubahan yang seperti ini yang tidak bisa diikuti oleh BI
3. Ketidakmampuan menentukan skala bisnis karena kurangnya integrasi proses bisnis dan otomatisasinya

4. Pengguna sistem tidak diberitahu atas kejadian yang terjadi pada sistem yang lainnya

5. Mencocokan ulang data ke dalam sistem yang berbeda

6. Redundansi data yang besar

7. Konflik perlakuan kepada konsumen oleh customer service, pemasaran dan penjualan pada channel channel yang berbeda

\section{KESIMPULAN}

1. Dengan adanya business intelligence maka dapat meningkatkan tingkat persaingan bisnis setiap perusahaan

2. Analisis data telah menjadi kebutuhan utama dan vital dalam upaya meningkatkan daya saing bisnis suatu perusahaan

3. Business intelligence merupakan aplikasi e-business yang berfungsi untuk mengubah data dalam perusahaan menjadi bentuk pengetahuan

4. Proses analisis berfungsi untuk mengubah data mentah yang ada pada data warehouse menjadi suatu informasi bagi perusahaan

\section{DAFTAR PUSTAKA}

1. Herman, Yakub ( 2010 )" E-Business Terhadap Perkembangan Praktik Bisnis STIMIK Dharma Putra Tangerang

2. Mery Meliyanti Lasakar " Analisis dan Perancangan Sistem Informasi Untuk Siklus Pembelian Dan Penjualan Dalam Pengembangan Bisnis Online Shop Pada Holly Shop" Vol 2 No 2 ( 2013 )

3. Bambang Supradono dan Ayu Noviani Hanum ( 2011 ) “Peran Sosial Media Untuk Manajemen Hubungan Pelanggan Pada Layanan E-Commerce" Universitas Muhammadiyah Semarang

4. Abdurrahman Adi Sukma ( 2012 ) "Analisis Faktor-Faktor Yang Mempengaruhi Keputusan Pembelian Melalui Social 
Networking Websites" Fakultas

Ekonomi Universitas Gunadarma

5. Dewi Irmawati ( 2011$)$

"Pemanfaatan E-Commerce Dalam

Dunia Bisnis "Staf Pengajar Jurusan

Manajemen Informatika Politeknik Negeri Sriwijaya

6. Eka Miranda " Pengembangan

Business Intelligence Bagi

Perkembangan Bisnis Perusahaan" Jurusan Sistem Informasi Fakultas Ilmu Komputer Universitas Bina Nusantara Volume 02 Nomor 02 Oktober 2008

7. Rina Indriyani ( 2013 ) Decision Support System “ Business Intelligence " Fakultas Ekonomi Akuntansi- S1 Universitas Islam "45" Bekasi 